\title{
Korkulu Rüya Anafilaksi: Tek Merkez Deneyimi
}

\section{Fearful Dream Anaphylaxis: One Center Experience}

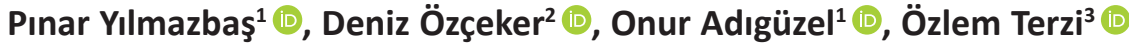

\author{
${ }^{1}$ Sağlık Bilimleri Üniversitesi, Prof. Dr. Cemil Taşçığlu Şehir Hastanesi, Çocuk Kliniği, İstanbul, Türkiye \\ ${ }^{2}$ Sağlık Bilimleri Üniversitesi, Prof. Dr. Cemil Taşçıŏlu Şehir Hastanesi, Çocuk Alerji Kliniği, İstanbul, Türkiye \\ ${ }^{3}$ Ondokuz Mayıs Üniversitesi, Tıp Fakültesi, Halk Sağlığı Anabilim Dalı, Samsun, Türkiye
}

ORCID ID: P.Y. 0000-0002-1283-1712; D.Ö. 0000-0002-0032-6727; O.A. 0000-0002-5778-6580; Ö.T. 0000-0002-9524-5582

Attf/Citation: Yilmazbas P, Ozceker D, Adiguzel O, Terzi, O. Korkulu rüya anafilaksi: Tek merkez deneyimi. Çocuk Dergisi - Journal of Child 2021;21(1):42-47. https://doi.org/10.26650/jchild.2021.1.810639

öz

Amaç: Anafilaksi hızlı ve doğru müdahale edilmediğinde ölümcül olabilen sistemik bir reaksiyondur. Çalışmamızın amacı çocuk alerji polikliniğine anafilaksi nedeni ile başvurmuş olan hastaların demografik özellikleri, klinik seyri ve tetikleyici etkenlerini paylaşmaktır.

Gereç ve Yöntem: 2017-2020 yılları arasında anafilaksi tanısı ile çocuk alerji polikliniğinde tetkik edilmiş olan hastaların dosyaları geriye dönük olarak değerlendirildi.

Bulgular: Çalışmamıza dahil edilen 57 anafilaksi hastasının yaş ortalaması $7,8 \pm 4,5$ yıl idi, $\% 56,1^{\prime}$ i erkekti. Hastaların $\% 68,4^{\prime}$ ü atopik idi, $\% 49,1^{\prime}$ inde serum IgE yüksekliği, \%36,8'inde eozinofili eşlik etmekteydi. Tetikleyici olduğu belirlenen alerjenler sırasıyla besinler $(\% 40,4)$, ilaçlar $(\% 35,1)$ ve venom $(\% 5,3)$ idi. Hastaların \%64,9'unda hafif şiddette anafilaksi gözlendi. Eşlik eden ek alerjik hastalık, astım ve atopi varlığının anafilaksi şiddetini arttırdığı görüldü. Dokuz hastada 2 veya daha fazla anafilaksi atağı gözlenmiş idi. Adrenalin oto-enjektörü reçete edilmiş olan hiçbir hastada atak esnasında oto-enjektör kullanılmamıştı.

Sonuç: Anafilaksi erkek çocuklarda daha sık görülmektedir. En sık tetikleyici etken besinlerdir. Astım, eşlik eden alerjik hastalık ve atopi varlığı atak şiddetini arttıran etmenlerdir. Adrenalin oto-enjektörü reçete edilmiş olan hastalarda da kullanılmamaktadır.

Anahtar Kelimeler: Anafilaksi, çocuk, besin alerjsi, adrenalin oto-enjektörü

\section{GíRiş}

Anafilaksi, ani başlayan ve ölüme yol açabilen, ciddi, sistemik bir alerjik reaksiyon olarak tanımlanmaktadır (1). Gerçek insidansı yetersiz bildirim ve teşhise bağlı olarak bilinmemekle birlikte, 0-4 yaş grubunda insidansının 3 kat fazla olduğu ve tüm yaş gruplarında insidansının artmakta olduğu belirtilmektedir (24). Anafilaksiye bağlı fatalite $\% 0,001$ oranında bildirilmiştir ve anafilaksi görülme oranında artmaya rağmen fatalite oranında

\section{ABSTRACT}

Objective: Anaphylaxis is a systemic reaction that can be fatal if not treated quickly and correctly. The aim of our study is to share the demographic characteristics, clinical course and triggering factors of the cases diagnosed with anaphylaxis in the pediatric allergy outpatient clinic. Material and Method: The files of the cases with a diagnosis of anaphylaxis who were examined in the pediatric allergy outpatient clinic between the years 2017-2020, were evaluated retrospectively.

Results: The average age of the 57 anaphylaxis cases included in our study was $7.8 \pm 4.5$ years, $56.1 \%$ were male. Of the cases, $68.4 \%$ were atopic, $49.1 \%$ had elevated serum IgE levels and $36.8 \%$ were accompanied by eosinophilia. Triggering allergens were foods $(40.4 \%)$, drugs (35.1\%) and venom (5.3\%) respectively. Mild anaphylaxis was observed in $64.9 \%$ of cases. It was observed that accompanying allergic diseases, asthma and presence of atopy increased the severity of anaphylaxis. Two or more anaphylaxis attacks were observed in nine cases. None of the cases, who were prescribed adrenaline auto-injector, used the adrenaline autoinjector during the attack.

Conclusion: Anaphylaxis cases are more common in boys. The most common triggering factor is food. Asthma, concomitant allergic diseases and the presence of atopy are factors that increase the severity of attacks. Adrenaline auto-injector is not used in cases where it has been prescribed.

Keywords: Anaphylaxis, child, food allergy, adrenaline auto-injector

bir artış olmamıştır (5). Anafilaksi vakalarında tetikleyicilere bakıldığında çocukluk yaş grubunda besinler ilk sırada yer almakta, bu besinlerin çeşitleri coğrafyaya ve yerel beslenme alışkanlıklarına göre değişkenlik göstermektedir $(6,7)$.

Çalışmamızın amacı üniversiteye afiliye bir eğitim ve araştırma hastanesi Çocuk İmmünoloji ve Alerji Kliniği'ne anafilaksi nedeni ile başvurmuş olan vakaların demografik özellikleri, klinik seyri ve tetikleyici etkenlerini paylaşmaktır.

Sorumlu Yazar/Corresponding Author: Pınar Yılmazbaş E-mail: drpinary@yahoo.com

Başvuru/Submitted: 14.10.2020 • Revizyon Talebi/Revision Requested: 26.01.2021 • Son Revizyon/Last Revision Received: 26.02 .2021 • Kabul/Accepted: 04.03.2021 


\section{GEREÇ VE YÖNTEM}

Vakalara anafilaksi tanısı 2005 yılında yapılan İkinci Anafilaksi Tanım ve Tedavi Sempozyumu'nda belirlenen klinik tanı ölçütlerine göre konuldu (8).

Üç kriterden herhangi birisinin olması durumunda anafilaksi kabul edildi.

Kriterler:

1. Akut olarak ortaya çıkan deri, mukoza veya ikisine ait tutulum belirtileri ve aşağıdakilerden en az biri:

a. Solunum sıkıntısı

b. Kan basıncında düşme veya uç organ fonksiyon bozukluğu ile ilgili semptomlar

2. Hastanın olası bir alerjene maruziyetinden hemen sonra aşağıdakilerden en az iki veya daha fazlasının oluşması:

a. Deri, mukoza veya ikisine ait tutulum belirtileri

b. Solunum sıkıntısı

c. Kan basıncında düşme veya uç organ fonksiyon bozukluğu ile ilgili semptomlar

d. Gastrointestinal sistem belirtileri

3. Hasta için bilinen bir alerjenle maruziyetten sonra kan basıncında düşme

\section{Laboratuvar Tetkikleri}

Hastaların dosyalarından var olan eozinofil yüzdesi, serum total immünglobulin E (Ig E), şüpheli tetikleyicilere yönelik bakılmış olan serum spesifik IgE değerleri kayıt edildi.

Şüpheli besin için bakılan spesifik IgE değeri eşik değerin üzerinde ise anlamlı kabul edildi.

Atopi: Hastaların geçmiş öyküleri, mevcut deri test duyarlılıkları ve spesifik IgE’leri değerlendirilerek tanımlandı.

Hastaların başvuru anındaki öykülerine göre anafilaksi şiddeti belirlendi (Tablo 1) (9).

\section{Verilerin Toplanması}

Prof. Dr. Cemil Taşcıoğlu Şehir Hastanesi Çocuk İmmünoloji ve Alerji Kliniği'ne 30 Ocak 2017- 20 Temmuz 2020 tarihleri arasında başvuran, 1 ay-18 yaş arası anafilaksi ta- nısı konulan hastaların tıbbi kayıtları geriye dönük olarak değerlendirildi.

Hastaların demografik, klinik ve laboratuar bulguları retrospektif olarak dosyalarından kayıt edildi. Hastaların yaşı (yıl), cinsiyeti, ailede atopi öyküsü, anafilaksiden sorumlu ajan, ek alerjik hastalık varlığı, anafilaksinin ağırlık derecesi, anafilaksi sırasında uygulanan tedavi, daha önceden veya anafilaksi atağı sonrasında adrenalin oto-enjektörü reçete edilip edilmediği ve atak sırasında adrenalin oto-enjektörü kullanıp kullanmadığı, yapılmış olan laboratuvar testlerinden hemogram, total IgE ve serum spesifik IgE değerleri incelemeye alındı.

Çalışmamız için Prof. Dr. Cemil Taşçıŏlu Şehir Hastanesi Etik Kurulu'ndan 48670771-514.10 no'lu izin alındı.

\section{İstatistiksel Analizler}

Araştırmadan elde edilen veriler kodlandıktan sonra SPSS (Version 22 for Windows, SPSS Inc, Chicago, IL, USA) paket programında bilgisayara aktarıldı ve analiz edildi. Veriler değerlendirilirken sürekli değişkenler ortalama sstandart sapma ile frekans veriler ise sayı ve yüzde (\%) ile ifade edildi. İstatistiksel analizlerde ölçümsel değişkenlerin normal dağılıma uygunluğu "ShapiroWilk Testi" ile değerlendirildi ve veriler normal dağılıma uymadığı için gruplar arası karşılaştırmada Mann-Whitney U testi kullanıldı. Kategorik verilerin gruplar arası karşılaştırmasında ise Pearson ki-kare testi kullanıldı. İstatistiksel anlamlılık düzeyleri tüm testler için $p<0,05$ olarak kabul edildi.

\section{BULGULAR}

Anafilaksi nedeni ile başvuran 57 çocuğun yaş ortalaması $7,8 \pm 4,5$ ( $\min =1-\max =17)$ yıl idi ve $32(\% 56,1)$ 'si erkekti. Hastaların \%59,6'sı 4-12 yaş grubundaydı (Tablo 2). Erkek çocuk-

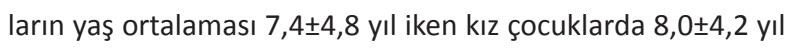
idi ve yaş açısından cinsiyetler arası fark yoktu $(p=0,19)$. Hastaların 37'sinde $(\% 64,9)$ hafif şiddette anafilaksi gözlenirken, 7 'si $(\% 12,3)$ ağır anafilaksi olarak değerlendirildi. Hastaların 15 'inde $(\% 26,3)$ solunum yolu alerjisi, $7(\% 12,3)$ hastanın ailesinde atopi öyküsü mevcuttu. Hastaların ortalama IgE değerleri $278,7 \pm 321,2 \mathrm{kIU} / \mathrm{L}$ iken, ortalama eozinofil düzeyleri ise 4,4 $\pm 4,3$ bin hücre/mcL idi (Tablo 2).

Tablo 1: Anafilaktik reaksiyonun klinik şiddetine göre derecelendirilmesi.

\begin{tabular}{|c|c|c|c|c|c|}
\hline & Deri/mukoza & Gastarointestinal sistem & Solunum sistemi & Kardiyovasküler sistem & Nörolojik sistem \\
\hline Hafif & $\begin{array}{l}\text { Yaygın kaşıntı, kızarıklık, } \\
\text { ürtiker, anjiyoödem }\end{array}$ & $\begin{array}{l}\text { Ağızda kaşıntı, } \\
\text { karıncalanma, dudakta hafif } \\
\text { şişme, bulantı, kusma, hafif } \\
\text { karın ağrısı }\end{array}$ & $\begin{array}{l}\text { Burun tıkanıklığı, hapşırma, } \\
\text { burun akıntısı, boğazda } \\
\text { kaşınma, hafif hışıltı }\end{array}$ & $\begin{array}{l}\text { Taşikardi (>15 atım/ } \\
\text { dakika artış) }\end{array}$ & $\begin{array}{l}\text { Aktivite seviyesinde } \\
\text { azalma ve anksiyete }\end{array}$ \\
\hline Orta & $\begin{array}{l}\text { Yukarıdakilerden } \\
\text { herhangi biri }\end{array}$ & $\begin{array}{l}\text { Yukarıdakilerden herhangi } \\
\text { biri, kramp tarzında karın } \\
\text { ağrısı, ishal, kusma }\end{array}$ & $\begin{array}{l}\text { Yukarıdakilerden herhangi } \\
\text { biri, boğuk ses, havlar } \\
\text { şekilde öksürük, stridor, } \\
\text { dipne, hışıltı }\end{array}$ & $\begin{array}{l}\text { Taşikardi (>15 atım/ } \\
\text { dakika artış) }\end{array}$ & $\begin{array}{l}\text { Baş dönmesi, ölüm } \\
\text { korkusu hissi }\end{array}$ \\
\hline Ağır & $\begin{array}{l}\text { Yukarıdakilerden } \\
\text { herhangi biri }\end{array}$ & $\begin{array}{l}\text { Yukarıdakilerden herhangi } \\
\text { biri, bağırsak kontrolünün } \\
\text { kaybı }\end{array}$ & $\begin{array}{l}\text { Yukarıdakilerden herhangi } \\
\text { biri, siyanoz veya oksijen } \\
\text { saturasyonunun <\%92 } \\
\text { olması, solunum durması }\end{array}$ & $\begin{array}{l}\text { Hipotansiyon, kollaps, } \\
\text { şiddetli bradikardi, kalp } \\
\text { durması }\end{array}$ & $\begin{array}{l}\text { Konfüzyon, bilinç } \\
\text { kaybı }\end{array}$ \\
\hline
\end{tabular}


Tablo 2: Hastalara ilişkin değişkenler.

\begin{tabular}{lll}
\hline Değişkenler & & $\mathbf{n}(\%)$ \\
\hline Yaş grubu (yıl) & $0-3$ & $8(14,0)$ \\
& $4-12$ & $34(59,7)$ \\
Cinsiyet & $13-17$ & $15(26,3)$ \\
& Erkek & $32(56,1)$ \\
Anafilaksi şiddeti & Kaz & $25(43,9)$ \\
& Orta & $37(64,9)$ \\
Ek alerjik hastalık & As̆ı̆ır ve/veya astıma eşlik & $15(26,3)$ \\
& eden alerjik rinit birlikteliği & \\
Ailede atopi öyküsü & & $8(\% 14,0)$ \\
Atopi varlı̆ı & Atopik dermatit & $7(12,3)$ \\
IgE (kıU/L) & $278,7 \pm 321,2$ & $39(\% 68,4)$ \\
Eozinofil (\%) & $4,4 \pm 4,3$ & $195,0(4-1451)$ \\
\hline
\end{tabular}

Serum total Ig E değeri $\geq 100 \mathrm{kIU} / \mathrm{L}$ olan hasta sayısı $28(\% 49,1)$ iken, $21(\% 36,8)$ hastanın eozinofil yüzdesi $\geq 4,0$ idi. Yapılan değerlendirmede $39(\% 68,4)$ hastanın atopik olduğu belirlendi.

Hastaların 48'inin $(\% 84,2)$ ilk atakla geldiği tespit edildi. İki veya daha fazla atak geçirdiği belirlenen $9(\% 15,8)$ hastanın 7'si erkek idi ve 5'i 4-12 yaş grubundaydı, 4'ü astım tanılıydı. Hastaların 4'üne adrenalin oto-enjektörü daha önce reçete edilmiş idi ancak hiçbir aile atak sırasında oto-enjektörünü kullanmamışt. Tekrarlayan atakları olan 9 hastanın 4'ünde atopi hikayesi mevcuttu ancak atopi ile tekrarlayan atak geçirme arasında ilişki
Tetikleyiciler

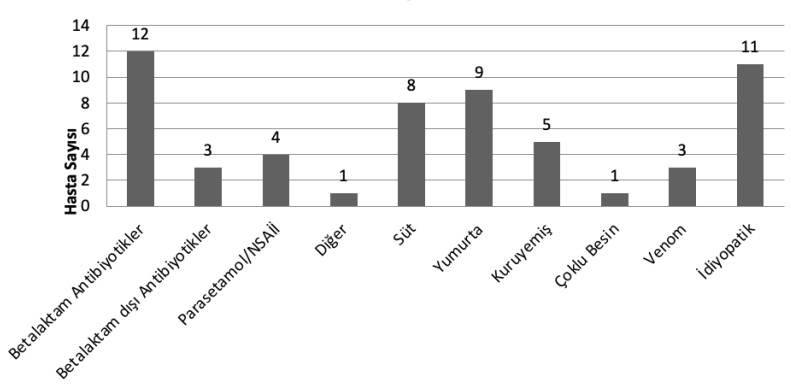

Şekil 1: Hastalardaki tetikleyici faktörlerin dağılımı.

tespit edilmedi. İlk atak ve tekrarlayan (iki veya daha fazla) atak geçirme durumuna göre hastalar arasında yaş, serum total IgE ve eozinofil yüzdesi açısından istatistiksel olarak anlamlı fark yoktu (sırasıyla $p=0,33, p=0,07$ ve $p=0,08$ ). Bifazik reaksiyon gösteren hastamız bulunmamaktaydı.

Tetikleyici olduğu belirlenen alerjenler sırasıyla besinler $(\% 40,4)$, ilaçlar $(\% 35,1)$ ve venom $(\% 5,3)$ iken, $\% 19,3$ 'ünde idiyopatikti. Tetikleyicinin besinler olduğu 23 çocukta alerjenlerden sırasıyla 9'unda $(\% 39,1)$ yumurta ve $8^{\prime}$ inde $(\% 34,8)$ süt tespit edildi. Tetikleyicisi ilaç olan vakaların 12 'sinde $(\% 60,0)$ betalaktam antibiyotik ve 4'ünde (\%20) ise parasetamol/nonsteroidantiinflamatuvar (NSAi) ilaç duyarlılığı tespit edildi (Şekil 1).

Tekrarlayan atak geçirenlerin \%77,2'inde tetikleyici besinler iken, \%22,8'inde ilaçlardı. Astımı olan 15 hastanın 8'inde $(\% 53,3)$ ilaçlar en sık tetikleyici iken, 3 'ünde $(\% 20,0)$ besinler ve sadece 1 'inde $(\% 6,7)$ venomun tetikleyici olduğu belirlendi. Üç $(\% 20,0)$ astımlı hastada ise tetikleyici neden idiopatik idi. Astımı olmayanlarda ise en sık tetikleyicinin besinler $(\% 47,6)$ olduğu

Tablo 3: Anafilaksiyi tetikleyen faktörlerin değerlendirilmesi.

\begin{tabular}{|c|c|c|c|c|c|c|}
\hline & & $\begin{array}{l}\text { İlaç }(n=20) \\
n(\%)\end{array}$ & $\begin{array}{l}\text { Besin }(n=23) \\
n(\%)\end{array}$ & $\begin{array}{l}\text { Venom }(n=3) \\
n(\%)\end{array}$ & $\begin{array}{l}\text { İdiyopatik }(n=11) \\
n(\%)\end{array}$ & p \\
\hline \multirow[t]{2}{*}{ Cinsiyet } & Erkek & $9(28,1)$ & $15(46,9)$ & $3(9,4)$ & $5(15,6)$ & 0,20 \\
\hline & $\mathrm{Kız}$ & $11(44,0)$ & $8(32,0)$ & $0(0,0)$ & $6(24,0)$ & \\
\hline \multirow[t]{3}{*}{ Yaş grubu (yıl) } & $0-3$ & $1(12,5)$ & $7(87,5)$ & $0(0,0)$ & $0(0,0)$ & 0,16 \\
\hline & $4-12$ & $13(38,2)$ & $12(35,3)$ & $2(5,9)$ & $7(20,6)$ & \\
\hline & $13-17$ & $6(40,0)$ & $4(26,7)$ & $1(6,7)$ & $4(26,7)$ & \\
\hline \multirow[t]{3}{*}{ Anafilaksi Şiddeti } & Hafif & $18(48,6)$ & $12(32,4)$ & $3(8,1)$ & $4(10,8)$ & 0,001 \\
\hline & Orta & $2(15,4)$ & $9(69,2)$ & $0(0,0)$ & $2(15,4)$ & \\
\hline & Ağır & $0(0,0)$ & $2(28,6)$ & $0(0,0)$ & $5(71,4)$ & \\
\hline \multirow[t]{2}{*}{ İlk atak } & Evet & $18(37,5)$ & $16(33,3)$ & $3(6,3)$ & $11(22,9)$ & 0,07 \\
\hline & Hayır & $2(22,2)$ & $7(77,8)$ & $0(0,0)$ & $0(0,0)$ & \\
\hline \multirow[t]{2}{*}{ Ek alerjik hastalık } & Yok & $9(26,5)$ & $17(50,0)$ & $2(5,9)$ & $6(17,6)$ & 0,27 \\
\hline & Var & $11(47,8)$ & $6(26,1)$ & $1(4,3)$ & $5(21,7)$ & \\
\hline \multirow[t]{2}{*}{ Astım } & Yok & $12(28,6)$ & $20(47,6)$ & $2(4,8)$ & $8(19,0)$ & 0,23 \\
\hline & Var & $8(53,3)$ & $3(20,0)$ & $1(6,7)$ & $3(20,0)$ & \\
\hline \multirow[t]{2}{*}{ Ailede atopi öyküsü } & Yok & $16(3,3)$ & $20(41,7)$ & $3(6,3)$ & $9(18,8)$ & 0,57 \\
\hline & Var & $4(57,1)$ & $2(28,6)$ & $0(0,0)$ & $1(14,3)$ & \\
\hline \multirow[t]{2}{*}{ Atopi varlığı/tanısı } & Yok & $6(33,3)$ & $8(44,4)$ & $1(5,6)$ & $3(16,7)$ & 0,97 \\
\hline & Var & $14(35,9)$ & $15(38,5)$ & $2(5,1)$ & $8(20,5)$ & \\
\hline
\end{tabular}


Tablo 4: Anafilaksi şiddetini etkileyen faktörler.

\begin{tabular}{|c|c|c|c|c|c|}
\hline & & Hafif $(n=37)$ & Orta $(n=13)$ & Ağır $(n=7)$ & $\mathbf{p}$ \\
\hline \multirow[t]{2}{*}{ Cinsiyet } & Erkek & $20(62,5)$ & $7(21,9)$ & $5(156)$ & 0,68 \\
\hline & $\mathrm{K} ı \mathrm{Z}$ & $17(68,0)$ & $6(24,0)$ & $2(8,0)$ & \\
\hline \multirow[t]{3}{*}{ Yaş grubu (yıl) } & $0-3$ & $6(75,0)$ & $2(25,0)$ & $0(0,0)$ & 0,35 \\
\hline & $4-12$ & $23(67,6)$ & $8(23,5)$ & $3(8,8)$ & \\
\hline & $13-17$ & $8(53,3)$ & $3(20,0)$ & $4(26,7)$ & \\
\hline \multirow[t]{2}{*}{ İlk atak } & Evet & $31(64,6)$ & $11(22,9)$ & $6(12,5)$ & 0,99 \\
\hline & Hayır & $6(66,7)$ & $2(22,2)$ & $1(11,1)$ & \\
\hline \multirow[t]{2}{*}{ Ek Alerjik hastalık } & Yok & $19(55,9)$ & $12(35,3)$ & $3(8,8)$ & 0,02 \\
\hline & Var & $18(78,3)$ & $1(4,3)$ & $4(17,4)$ & \\
\hline \multirow[t]{2}{*}{ Astım } & Yok & 25 (595) & $13(31,0)$ & $4(9,5)$ & 0,04 \\
\hline & Var & $12(800)$ & $0(0,0)$ & $3(20,0)$ & \\
\hline \multirow[t]{2}{*}{ Ailede atopi öyküsü } & Yok & $30(62,5)$ & $12(25,0)$ & $6(12,5)$ & 0,14 \\
\hline & Var & $7(100,0)$ & $0(0,0)$ & $0(0,0)$ & \\
\hline \multirow[t]{2}{*}{ Atopi varlığı/tanısı } & Yok & $10(27,0)$ & $8(61,5)$ & $0(0,0)$ & 0,01 \\
\hline & Var & $27(69,2)$ & $5(12,8)$ & $7(17,9)$ & \\
\hline \multirow[t]{2}{*}{ Eozinofildüzeyi(bin hücre/mcL) } & $<4$ & $21(75,0)$ & $5(17,9)$ & $2(7,1)$ & 0,42 \\
\hline & $\geq 4$ & $13(62,0)$ & $4(19,0)$ & $4(19,0)$ & \\
\hline \multirow[t]{2}{*}{ IgE düzeyi (kIU/L) } & $<100$ & $9(64,3)$ & $4(28,6)$ & $1(7,1)$ & 0,48 \\
\hline & $\geq 100$ & $20(714)$ & $4(14,3)$ & $4(14,3)$ & \\
\hline
\end{tabular}

belirlendi. Ancak astım varlığı ile tetikleyiciler arasında istatistiksel olarak anlamlı bir ilişki yoktu $(p=0,25)$. En sık tetikleyici olarak ilaçlar; kız çocuklarında (\%44), >12 yaş olanlarda (\%40), hafif şiddette anafilaksi olanlarda $(\% 48,6)$, ek alerjik hastalığı olanlarda $(\% 47,8)$ ve ailede atopi öyküsü olanlarda $(\% 57,1)$ gözlenirken, besinlerin; erkek çocuklarda (\%46,9), 0-3 yaş arasında olanlarda $(\% 87,5)$, orta şiddette anafilaksi olanlarda $(\% 69,2)$ ve ek alerjik hastalığı olmayanlarda $(\% 50,0)$ daha sık tetikleyici olduğu belirlendi. Hastaların bazı özelliklerine göre tetikleyici grupların dağılımı Tablo 3'te görülmektedir.

Anafilaksi şiddetini etkileyen faktörler değerlendirildiğinde eşlik eden ek alerjik hastalık, astım olması ve atopi varlığının anafilaksi şiddetini artırdığı görüldü (sırasıyla p=0,02, p=0,04, p=0,01) ancak diğer faktörler ile ilişki tespit edilemedi (Tablo 4).

\section{TARTIŞMA}

Çalışmamız anafilaksi nedeni ile çocuk alerji kliniğinde takip edilmiş olan hastaların etiyolojilerini ve özelliklerini göstermektedir. Çalışma sonuçlarımıza göre anafilaksiye neden olan etkenlerin başında besinler gelmektedir. Besinleri sırası ile ilaçlar ve venom alerjisi takip etmiş, hastaların \%19,3'ünde etken saptanamamıştır. Daha önce çocuklar üzerinde yapılmış olan çalışmalarda da besinler en sık etken olarak gösterilmiş, atakların ortalama $1 / 5^{\prime}$ inde etken tespit edilememiştir (5-7).

Önceki çocukluk yaş grubundaki çalışmalar ile uyumlu olarak anafilaksi vakalarımızın çoğunluğunu $(\% 56,1)$ erkek çocuklar oluşturmaktadır $(7,10,11)$. Çalışmamızda en sık $(\% 64,9)$ oranda hafif şiddette anafilaksi tespit edildi. Diğer çalışmalarda hafif anafilaksi oranı yüksek olanlar olduğu gibi, orta şiddette atak oranı daha sık saptanan çalışmalar da bulunmaktadır $(11,12)$. Çalışmamızda diğer çalışmalar ile uyumlu olarak atak şiddeti ile cinsiyet, yaş, serum total IgE düzeyi, eozinofili, tekrarlayan atak olması ve ailede atopi öyküsü bulunması arasında ilişki bulunamadı $(11,12)$. Bunun yanı sıra, ek alerjik hastalık, eşlik eden astım ve atopi varlığı atak şiddetini arttıran faktörler olarak tespit edildi. Daha önceki çalışmalarda da astımın eşlik etmesi ciddi anafilaksi için risk faktörü olarak bildirilmektedir $(13,14)$. Bu nedenle özellikle astımın eşlik ettiği besin alerjisi olan vakalarda astımın kontrol altında olması önem kazanmaktadır.

Tetikleyicinin besinler olduğu 23 çocukta alerjenlerden sırasıyla en sık olarak 9'unda yumurta, $8^{\prime}$ inde süt, $5^{\prime}$ inde kuruyemiş, 1 hastada ise çoklu besin alerjisi tespit edilmiştir. Anafilaksi hastalarında çocuklarda tetikleyici olarak besinler ilk sırada yer almaktadır (15). Anafilaksiye neden olan besin çeşitleri coğrafi konum ve beslenme alışkanlıklarına göre değişmektedir. Uzak doğuda en sık tetikleyici ajan kabuklu deniz ürünleri olarak kaydedilmiş iken, Amerika'da yer fistığı, Avrupa'da yumurta, inek sütü, yer fistığ en sık tetikleyici ajan olarak saptanmıştır $(6,10,16)$. Ülkemizden yapılan diğer çalışmalarda süt ürünleri, yumurta, çerezler en sık tespit edilen besinler olmuştur $(7,11)$.

Çalışmamızda ikinci sıklıkta tetikleyici ajan olarak ilaçlar tespit edildi. Diğer çalışmalar ile uyumlu olarak yaş arttkça anafilaksi etkeni olarak ilaçların tespit edilme oranının da arttı̆ı görüldü $(9,17,18)$. Çalışmamıza benzer olarak daha önceki çalışmalarda 
da en sık antibiyotikler (betalaktamlar ilk sırada) tespit edilmiş bunu NSAi ilaçlar izlemiştir $(4,7,11)$.

Çalışmamızda \%15,8 oranında tekrarlayan anafilaksi tespit edilmiştir. Tekrarlayan atak geçiren 9 hastada en sık tetikleyici olarak besinler $(\% 77,2)$ ilk sırada yer alırken, ikinci sırayı ilaçlar $(\% 22,8)$ izlemiştir. Diğer çalışmalarda da en sık besinler tekrarlayan ataklardan sorumlu tutulmuşlardır (7,9-11). İlaç alerjilerinde, ailenin bildirmesi halinde doktor o ilacı reçete etmemektedir, ancak besin içerikleri her zaman çok ayrıntılı incelenmediği, besin etiketi okuma alışkanlığı tam olarak yerleşmediği için tekrarlayan atakların besinler ile meydana gelmesi kaçınılmazdır.

Vakalarımızdan 4'üne adrenalin oto-enjektörü reçete edilmiş, hiçbiri atak esnasında oto-enjektörü kullanmamıştır. Diğer çaIışmalarda da reçete edilmiş olan adrenalin oto-enjektörü kullanımının yeterli olmadığı belirtilmiştir $(9,10)$. Ailelerin oto-enjektör kullanımı ile ilgili eğitiminin daha etkin olarak yapılması gerektiği görülmektedir.

Yaşlara göre tetikleyici ajanlara baktığımızda 0-3 yaşta en sık besinler, 4-12 yaşta ilaçlar, 12 yaş üstünde ilaçlar olduğunu görmekteyiz. Hayatın ilk yıllarında besinlerin etken olması beklenen bir durumdur. Yaşla birlikte tetikleyici etkenin ilaç olma sıklığında artş önceki çalışmalarda da gösterilmiştir $(9,17,18)$. Burada yaş ile birlikte artan ilaç kullanımının da etkili bir faktör olduğu düşünülebilir.

Çalışmamızda diğer çalışmalara oranla daha az oranda etken olarak venom alerjisi \%5,3 tespit edildi. Çalışmamızın yapıldığı şehrin bir metropol olması, kırsal alandan gelen hastamızın olmaması bu düşük oranı açıklayabilmektedir. Venom nedenli anafilaksi hastalarının hepsinin erkek olması daha önceki çalışmalar ile de uyumlu idi $(9,17)$.

Anafilaksi hastalarının çoğunlukla IgE bağımlı olduğu bilinmektedir $(15,19)$. Hastalarımızın \%49,1'inde serum total IgE değeri yüksek saptandı. Ülkemizden yapılmış olan diğer 2 çalışmada da hastaların yarısından çoğunun IgE bağımlı olduğu gösterilmiştir $(9,11)$. Çalışmamızda diğer çalışmalar ile uyumlu olarak serum total IgE düzeyleri ile anafilaksi şiddeti arasında ilişki bulunamamıştır $(13,20)$.

Çalışmamızda 39 hastada $(\% 68,4)$ atopi saptanmıştır, Orhan ve ark.'ın çalışmasında bu oran \%59,1 iken, Vezir ve ark.'ın çalışmasında \%48,4'tür $(9,11)$. Orhan ve ark.'ın çalışmasında atopik hastalarda tekrarlama oranı yüksek saptanmamış iken Vezir ve ark.'ın çalışmasında atopik bireylerde tekrarlayan atak oranı yüksek bulunmuştur. Bizim çalışmamızda atopik hastalarda tekrarlama oranı yüksek saptanmadı ancak atopi varlığı ile atak şiddeti arasında pozitif ilişki saptandı.

Kısıtılık: Çalışmaya dahil edilen hastalarımızın acil kayıtları yetersiz olması nedeni ile uygulanan tedavileri ve anafilaksinin ilk saatlerinde alınması gereken serum triptaz düzeyini değerlendiremedik.

Sonuç olarak; anafilaksi hızlı ve doğru müdahale edilmezse ölümcül olabilen sistemik bir reaksiyondur. Tetikleyici nedenin her zaman tespit edilmesi mümkün olmasa da mutlaka ayrıntılı bir araştırma yapılmalı, aile ve hasta bilgilendirilmeli ve yazılı eylem planı verilmelidir. Çalışmamızda tetikleyici olarak en sık besinler tespit edilmiş olup, elinde adrenalin oto-enjektörü olan hiçbir hastanın anafilaksi sırasında uygulamadığı tespit edildi. Bu nedenle atak anında adrenalin oto-enjektörü kullanımı konusunda ailelere süreğen eğitim verilmesi gerektiğini düşünmekteyiz. Ülkemizde anafilaksi tanılı çocukların değerlendirildiği sınırlı sayıda çalışma olması nedeni ile çalışmamız ülke verilerimize katkıda bulunacaktır.

Etik Komite Onayı: : Bu çalışma için etik kurul onayı Prof. Dr. Cemil Taşçıoğlu Şehir Hastanesi Etik Kurulu'ndan alınmıştır (48670771514.10).

Bilgilendirilmiş Onam: Katılımcılardan bilgilendirilmiş onam alınmıştır.

Hakem Değerlendirmesi: Dış bağımsız.

Yazar Katkıları: Çalışma Konsepti/Tasarım- D.Y., P.Ö., O.A.; Veri ToplamaD.Y., P.Ö., O.A.; Veri Analizi/Yorumlama- Ö.T.,P.Y., D.Ö.; Yazı Taslağı- P.Y., D.Ö., O.A.; İçeriğin Eleştirel İncelemesi- Ö.T.,P.Y., D.Ö.; Son Onay ve Sorumluluk- P.Y., D.Ö., O.A., Ö.T.

Çıkar Çatışması: Yazarlar çıkar çatı̧̧ması beyan etmemişlerdir.

Finansal Destek: Yazarlar finansal destek beyan etmemişlerdir.

Ethics Committee Approval: This study was approved by Prof. Dr. Cemil Taşcioğlu City Hospital Ethics Committee (48670771-514.10).

Informed Consent: Written consent was obtained from the participants.

Peer Review: Externally peer-reviewed.

Author Contributions: Conception/Design of Study- D.Y., P.Ö., O.A.; Data Acquisition- D.Y., P.Ö., O.A.; Data Analysis/Interpretation- Ö.T.,P.Y., D.Ö.; Drafting Manuscript- P.Y., D.Ö., O.A.; Critical Revision of ManuscriptÖ.T.,P.Y., D.Ö.; Final Approval and Accountability- P.Y., D.Ö., O.A., Ö.T.

Conflict of Interest: Authors declared no conflict of interest.

Financial Disclosure: Authors declared no financial support.

\section{KAYNAKLAR/REFERENCES}

1. Anagnostu K. Anaphylaxis in children: epidemiology, risk factors and management. Curr Pediatr Rev 2018;14(3):180-186. doi: 10. 2174/1573396314666180507115115

2. Lee S, Hess EP, Lohse C, Gilani W, Chamberlain AM, Campbell RL. Trends, characteristics, and incidence of anaphylaxis in 2001-2010: A population-based study. J Allergy Clin Immunol 2017;139(1):1828. doi: 10.1016/j.jaci.2016.04.029

3. Rudders SA, Arias SA, Camargo CA Jr. Trends in hospitalizations for food-induced anaphylaxis in US children, 2000-2009. J Allergy Clin Immunol 2014;134(4):960-2. doi: 10.1016/j.jaci.2014.06.018

4. Tejedor-Alanso MA, Moro Moro M, Mugica Garcia MV. Epidemiology of anaphylaxis: contributions from the last 10 years. Clin Exp Allergy 2015;45(6):1027-39. doi: 10.1111/cea.12418 
5. Muraro A, Roberts G, Worm M, Bilo MB, Brockow K, Rivas FM, et al. Anaphylaxis: guidelines from the European Academy of Allergy and Clinical Immunology. Allergy 2014;69(8):1026-45. doi: 10.1111/ all.12437

6. Grabenhenrich LB, Dölle S, Moneret-Vautin A, Köhli A, Lange $\mathrm{L}$, Sprinder $\mathrm{T}$, et al. Anaphylaxis in children and adolescents: The European Anaphylaxis Registry. J Allergy Clin Immunol 2016;137(4):1128-37. doi: 10.1016/j.jaci.2015.11.015

7. Dogru M, Bostancı I, Ozmen S, Ginis T, Şenol H.D. The features of anaphylaxis cases followed in the pediatric allergy clinic. J Curr Pediatr 2017;15:12-8. doi:10.4274/jcp.58070

8. Sampson HA, Munoz-Furlong A, Campbell RL, Adkinson NF, Bock SA, Branum A, et al. Second symposium on the definition and management of anaphylaxis: summary report Second National Institute of Allergy and Infectious Disease/Food Allergy and Anaphylaxis Network symposium. J Allergy Clin Immunol 2006;47(4):373-80. doi: 10.1016/j.jaci.2005.12.1303

9. Orhan F, Civelek E, Şahiner ÜM, Arga M, Can D, Çalıkaner AZ, et al. Anaphylaxis: Turkish National Guideline 2018. Asthma Allergy Immunology 2018;16. doi:10.21911/aai.2018.1

10. De Swert LF, Bullens D, Raes M, Dermaux AM. Anaphylaxis in referred pediatric patients: demographic and clinical features, triggers, and therapeutic approach. Eur J Pediatr 2008;167:125161. doi: 10.1007/s00431-007-0661-2

11. Vezir E, Erkoçoğlu M, Kaya A, Toyran M, Özcan C, Akan A, et al. Characteristics of anaphylaxis in children referred to a tertiarty care center. Allergy Asthma Proc 2013;34:239-46. doi: 10.2500/ aap.2013.34.3654
12. Huang F, Chawla K, Jarvinen KM, et al. Anaphylaxis in a New York City pediatric emergency department: triggers, treatments, and outcomes. J Allergy Clin Immunol 2012;129(1):162-8, e1-3. doi: 10.1016/j.jaci.2011.09.018

13. Astier $C$, Morisset M, Roitel. Predictive value of skin prick tests using recombinant allergens for diagnosis of peanut allergy. J Allergy Clin Immunol 2006;118(1):250-6. doi: 10.1016/j.jaci.2006.04.053

14. Bock SA, Munoz-Furlong A, Sampson HA. Fatalities due to anaphylactic reactions to foods. J Allergy Clin Immunol 2001;107(1):191-3. doi: 10.1067/mai.2001.112031

15. Commins SP. Outpatient Emergencies: Anaphylaxis. Med Clin North Am 2017;101(3):521-36. doi: 10.1016/j.mcna.2016.12.003

16. Thong BY, Cheng YK, Leong KP, Tang CY, Chng HH. Anaphylaxis in adults referred to a clinical immunology/allergy centre in Singapore. Singapore Med J 2005;46:529-34.

17. Hoffer V, Scheuerman O, Marcus N, Levy Y, Segal N, Lagovsky I, et al. Anaphylaxis in Israel: experience with 92 hospitalized children. Pediatr Allergy Immunol 2010;22:172-7. doi: 10.1111/j.13993038.2010.00990

18. Alves B, Sheikh A. Age-spesific aetiology of anaphylaxis. Arch Dis Child 2001;85:349. doi: 10.1136/adc.85.4.348b

19. Simons FER. Anaphylaxis. J Allergy Clin Immunol 2010;125:S161-81. doi:10.1016/j.jaci.2009.12.981

20. Shreffler WG, Beyer K, Chu T-HT, Burks AW, Sampson HA. Microarray immunoassay: association of clinical history, in vitro IgE function, and heterogeneity of allergenic peanut epitopes. J Allergy Clin Immunol 2004;113(4):776-82. doi: 10.1016/j.jaci.2003.12.588 